\title{
An emerging trend of charismatic religiosity in the Evangelical Lutheran Church of Finland
}

\section{T} he membership rates of the Evangelical Lutheran Church are declining; thus its position in society is becoming more and more precarious. This article focuses on a description of how charismatic religiosity, as one possible answer to the challenges faced, has gained a foothold inside the Evangelical Lutheran Church of Finland and what might be the premises that have made its emergence within an institutionalized Evangelical Lutheran religion possible. Because of the several decades of work done by the association known as Spiritual Renewal in Our Church, the publication of the Bishops' Commendation, and the Church's awakening to the 'crisis of the folk church', more doors have been opened to collaboration and the search for sources of inspiration.

\section{Introduction}

This article presents a twofold question: what are the processes by which charismatic Christianity has gained more visibility and has become more acceptable in the polarised and diversified Evangelical Lutheran Church of Finland, and in relation to what other phenomena can this trend be explained? The aim of this chapter is to focus on a description of how charismatic religiosity has gained a foothold inside the Evangelical Lutheran Church of Finland (henceforward the $\mathrm{ELCF}^{1}$ ) and what might be the premises

1 In this article I will use the acronym ELCF when referring the Evangelical Lutheran Church of Finland as an organisational institution and denomination. However, the word 'church' will be used in those situations where either it is used in the source materials (kirkko/church) or it is used as a theological concept (for example the 'church' as the 'body of Christ'). that have made this 'new' visibility of charismatic Christianity inside an institutionalized Evangelical Lutheran religion possible.

When referring to something as 'new' - and especially in this case - one has to offer some explanatory remarks. Charismatic Christianity has been part of Evangelical Lutheranism, but it has been located in the sphere of revival movements inside the ELCF or as a tradition of like-minded individuals (Anderson 2014: 95; Heininen and Heikkilä 1997: 152-3, 170; Huotari 1981: 172). Furthermore charismatic Christianity has existed on the fringes amongst more traditional and commonly-shared expressions of faith inside the ELCF. The charismatic revivals, historical as well as contemporary, have been in some cases even despised, rejected, or at least ignored among the majority of the ELCF's members and employees ${ }^{2}$ (Heino 1997: 61; Mantsinen 2014: 19, 23; Ruohomäki 2014: 447-50; Hiltunen 2002; Salonen et al. 2000: 279). In some contemporary cases, for example the Nokia Mission, the ELCF has interfered in these revivals when they have been considered to be contravening Evangelical Lutheran theology (Puumala 2007, Pihkala 2000). What is new then? It is not the 'acquired importance' which is new, nor the 'effect' - about which it is too early to make any elaborate statements - but rather the emergence of charismatic Evangelical Lutheranism, where the

2 The Catholic and Protestant denominations have a rather long history of rejecting Pentecostal movements and more lively forms of charismatic Christianity (Synan 2001). Thus the developments and ELCF's attitudes towards Pentecostal and charismatic religiosity is in line with earlier developments outside of Finnish society. 
charismatic tendencies in the expression of religiosity have become more acceptable and thus more visible in everyday life in Evangelical Lutheran parishes.

Changes in religiosity in the twenty-first century are often described as a process in which people's affiliation to institutionalised denominations is in decline and at the same time an interest in spirituality which answers the individual's religious needs is on the rise (Gillant-Ray 2005: 358). The increasing value of lay activities and volunteering, as well as the processes of emphasising individual experience and affections in the institutionalised church and its parish operations (Kääriäinen et al. 2005: 261) are not to be explained merely by the lack of resources, but also by changes in religiosity and the rise of spirituality, as reported by Grace Davie (1994, 2000, 2004), Grace Davie and others (2003), Abby Day (2009, 2010), Paul Heelas and Linda Woodhead (2007) and Linda Woodhead (2009). The trends of conservative and fundamentalist forms and interpretations of Christianity, such as evangelical and Pentecostal charismatic, are gaining more influence in the Christian field globally; furthermore, particularly neo-charismatic Christianity has been seen to be a product of modernity and secularisation (Iqtidar and Lehmann 2012: 2, 4).

The ELCF is facing a problem that seems unsolvable. Membership rates are declining and as a consequence its 'prosperity of wealth and souls' is becoming more and more unreliable (Palmu et al. 2012: $11-58,315-32)$. The vision of the ELCF is no longer an all-encompassing one, and furthermore parish ${ }^{3}$ members and believers are moving between religious communities without tying themselves to one denomination for life (Palmu et al. 2012: 11-58; Gilliat-Ray 2005: 366). Similar developments amongst Catholicraised Québécois have been reported, when individualised constellations of faith and a diminishing value of church-based religiosity, as well as circulation between different religious/spiritual groups has been found (Meintel 2014: 197).

The ELCF emphasises on their homepage that ELCF is not a 'state church' in the sense of a legis-

3 In this article I use the word 'parish' when referring to an administrative and autonomous unit of the Evangelical Lutheran Church of Finland; however, in some cases I will use the word 'congregation'. In those cases I want to emphasise that the congregation is a community of different individuals, furthermore, the emphasis is on the social relations of those individuals in a given community. lative concept, but a 'folk church', or an 'integral part of national history and culture' (see, e.g., $\mathrm{CS}^{4}$ ). The statistics, however, speak their cruel language. Furthermore, those statistics are assiduously read among ELCF's personnel and often referred to by its representatives in discussions concerning the role and importance of the ELCF and the part it plays in the societal environment. This creates a specific 'reality', where simultaneously the concepts of ELCF as an 'integral part of national culture' and the ELCF as an 'institution losing its significance' collide. This paradox can be understood as one of the reasons why the ELCF actively seeks various channels and new ways to participate in societal discussions and present itself as an active, important and prestigious actor at the societal level.

The challenges, such as the diminishing value of church-based religiosity and the decline in the magnitude of active church-goers are scrutinised, debated, and handled in various reports, strategies, seminars, meetings and discussions provided by the different bodies of the ELCF. The ELCF employees and various bodies of its organisation are trying to find a solution to these problems as well as, at the same time, the causes of these changes. Often such concepts as postmodernity, post-secularity, secularisation, spirituality and individuality are emphasised in these discussions (e.g. CMS 2014). Secularisation is frequently mentioned in various ELCF's reports and texts as one of the reasons underlying the diminishing value of churchbased religiosity, as well as a growing critique of the ELCF. Even though the ELCF bodies use the concept 'secularisation' however, they also use the term 'postsecularisation' simultaneously. ${ }^{5}$ Charismatic religiosity is often seen amongst some employees of the ELCF as an intriguing means of halting this unwanted change in the ELCF, because it is thought to provide more personalised ways of expressing spirituality.

4 Due to a large number of electronic sources and web page sources pertaining to this article, I have chosen to use an acronym notification system throughout when I refer to internet sources. The complete list of electronic materials used is provided in the list of references.

5 The traits of the academic secularisation paradigm critique as well as new spirituality and post-secularisation critique are also visible inside the ELCF reports and strategies since the conclusions are often based on academic research on change in religiosity (e.g., Taira 2015: 95-118; Flanagan and Jupp 2007; Coleman 2000: 3-4). 
to perfect an example as it gets of the 'problematic parishes' - characterised by, for example, a declining membership and a changing religious environment where other denominations and religious groups are gaining stronger footholds - as any of the other city parishes of the ELCF. ${ }^{7}$ As parishes are somewhat autonomous in their operations and chosen paths, the decisions made at the congregational level are often rather tied to individuals, and their personal interests, worldviews and affiliations. ${ }^{8}$ The parish employees are very interested in developing new forms and operations, as well as seeking collaboration and cooperation possibilities with various organisations and associations inside and outside the ELCF's realm, in order to solve the problem of the diminishing value of Evangelical Lutheranism in Finnish society (FN2012, FN2013). Amongst important collaborators at the congregational level are revival associations and organisations that promote charismatic Christianity, for example SROC, with which St Michael's parish has a close connection.

The association promoting charismatic Christianity (SROC) was initially registered on 29 December 1989 (NBPR). On their homepage SROC describes its vision thus: 'Spiritual Renewal supports and constructs communities that live in "the strength of the Holy Spirit" and send the members of those communities out to share the mission' (SROC/ Mission). The mission statement thus clearly presents two purposes. Firstly SROC aims to build several communities that emphasise charismatic Evangelical Lutheranism, and secondly encourage evangelisation

or the park beside the church, called Mannerheim's Park. However, the Paakarla-Pansio parish house has its own profile and an active group of employees and volunteers working to solve the socio-economic problems in that specific area (FN2011, FN2012).

7 A total of 500 members resigned from the Evangelical Lutheran Church of Finland in the St Michael's parish area in the year 2014 and at the same time, it gained 113 new members. The percentile change was 24.1 per cent more resignations when compared to the previous year; however, St Michael's situation was not the worst. There are several other parishes where the loss of the members was even greater. The decline in membership has been accelerating throughout the twenty-first century (see SC).

8 A pastor, a deacon, a youth worker or a chaplain has an organisational responsibility for some core operation, for example youth work or renewal, and he/she has a free hand to plan the work inside that specific operational area (FN2012). and missionary work in charismatic Christianity. This work is to be done inside the Evangelical Lutheran parishes and in cooperation with the ELCF as an institution. The SROC mission's aims are:

1) To encourage continuous spiritual revival among the Evangelical Lutheran parishes, church revival movements and other communities in the ELCF;

2) To emphasise the significance of the charismas, the Holy Spirit, prayer and unity among Christian denominations, communities and individual Christians;

3) To clarify the biblical and theological premises, substance, mission and meaning of charismatic Christianity in the Church, in cooperation with several Church-related operators;

4) To educate and transmit spirituality and to act in parishes and with parishes in order to strengthen individual affiliation to given denominations, as well as operate as a mediator between different denominations. (SROC/Mission)

SROC organises seminars within an affiliated association named the Church Builders' Forum. Neither SROC or the CBF have any administrative or institutional connection with the ELCF, but are external organisations collaborating with the ELCF.

\section{The ELCF's notion of a 'problematic religious environment', changes in religiosity and the need for personalised spiritualities}

Developments in the religious landscape of Finland and the ELCF's situation have prompted the ELCF to scrutinise its internal as well as external influences. The most commonly encountered descriptions of ELCF's internal development state that the ELCF is considered to be polarised and polyphonic (Palmu et al. 2012, OCSC, CoE 2015). Even though the ELCF is highly organised and has a centralised administration that steers the ELCF as a whole, as well as providing guidelines, there exist multiple interpretations and frameworks by which movements, communities and even individuals inside the ELCF deem what constitutes Evangelical Lutheranism. These interpretations often collide, sparking debates within the ELCF (CoE 2015: 10-11).

An interesting line to follow in this respect is to look more closely at how the contemporary religious landscape and its religiosity is represented inside the 
ELCF. It is spelt out in the strategic documents that Finnish religiosity has changed its form. This change is characterised as a process of a decline in the value of affiliation to the Church as an institution, and decreasing levels of participation in its operations. At the same time, belief in various aspects of the dogma and teaching has also decreased (Palmu et al. 2012; OCSC 2007: 9; CoE 2015: 3-5). This change, as presented in the Our Church strategy (OCSC), is based on religious privatisation and individualisation. This situation can be described in terms of three major clauses:

1) The search for salvation has moved into the private sphere, where the search for the meaning of life is mostly seen as a matter of individual endeavour;

2) Individuals construct their own meaningful worldview from the religious and/or spiritual elements available to them;

3) These choices are detached from traditional religious authorities' sphere of influence. According to the strategic documents, religious identities are 'created through processes of individual searching' and furthermore, religion is increasingly attached to experiences and social relationships rather than a lineage of tradition passed on from one generation to another. (OCSC 2007:

11)

This strategy draws heavily on research undertaken by the Church Research Centre and statistics provided by the ELCF. ${ }^{9}$

The ELCF's rationale of the problems they have is plausible. The decline in affiliation to the ELCF is focused on the larger cities, but at the same time the Church has re-established its strong foothold in the smaller towns, villages and rural areas (CSC; Palmu et al. 2012: 73-5; Pesonen and Vesala 2007: 282-4). However, it is important not to look solely at the statistics and overall membership rates, but to focus on the rates of those who consider themselves to be committed to the ELCF and its mission. A drastic decrease can be found in the numbers of

9 For example they draw these conceptualisations from Borg et al. (2007), Kääriäinen et al. (2003) and Mikkola et al. (2006) as well as Kirkon tilastollinen vuosikirja 2006, all of these either published by the ELCF or the research institution affiliated to the ELCF. those who have not even considered resignation ${ }^{10}$ from the Church (Palmu et al. 2012: 85). This development indicates a general attitudinal change, where the Church is no longer considered to be the binding agent of Finnish culture, or to have retained intact its important role in the everyday lives of Finnish people.

Archbishop Kari Mäkinen has on several occasions placed this question of change in religiosity under scrutiny. In 2011 Mäkinen gave the opening speech at the Evangelical Lutheran Church of Finland's Synod. He described the ELCF as a polyphonic community. This description can be understood as presenting a twofold problem. Firstly, the variations, and even conflicts, in the interpretation of the Bible and the interpretation of faith, and the worldviews 'behind' the faiths of individuals and groups, are an integral part of Evangelical Lutheranism. Secondly, these variations are not merely related to the times to 'postmodern society' - but is also something that has prevailed as a strong undercurrent in the history of Christianity since the early years of the Christian church. This 'tug-of-war', according to Mäkinen, between various interpretations and groups with differing worldviews inside the church is first and foremost a source of lively self-criticism which helps the church as a whole to develop, as well as providing an answer to the challenges in any given historical and contemporary environment and situation (see Mäkinen 2011). However, Mäkinen leans towards the idea of the 'Evangelical Lutheran' as a collective identity which, although diverse, is one where traditional as well as new forms of spirituality co-exist. Yet participation or even affirmed shared religious identities do not imply that the significance of the

10 The percentage dropped from 38 (2007) to 19 (2011). The membership of the Evangelical Lutheran Church of Finland numbered 4,221,965 members at the end of the year 2014 and the total population of Finland was $5,471,753$ inhabitants. In the St Michael's parish the membership numbered 20,221 parish members, where the total number of memberships in the Turku and Kaarina Parish Union was 147,100. The total number of people living in the Turku and Kaarina Parish Union area was 215,975 people in 2014 (see $\mathrm{CM}, \mathrm{SC}, \mathrm{OSF}$ ). These numbers are given to indicate the ratio of members and non-members of the Church and to illustrate the environment in which the parish, and the Church as a unity of multiple parishes as well as an institution, operates. In total the membership rates have declined throughout the twenty-first century. 
connection to a religious institution plays a greater role than personal affinities (Meintel 2014: 204). This is recognised and repeated at all the administrative levels of the ELCF; for example in the Church of Encounter strategy this weakened commitment to the ELCF and a rise in individualised spirituality is addressed in multiple entries (see CoE 2015: 10).

Individual opportunities to express one's faith under the umbrella of Evangelical Lutheranism are considered to be one of the key factors in preserving the ELCF's position and significance in the everyday lives of its members as well as in society as a whole (OCSC 2007, CoE 2015, Mäkinen 2011). In the 'Church of Encounter' ('Kohtaamisen kirkko', CoE 2015) the position of the ELCF is described in terms of a tightrope walk: ' $[\mathrm{t}] \mathrm{o}$ live with the disparity between a person-centred society and a communal approach ... [t] he church must be able to take into account the individuality of people' ( $\mathrm{CoE} 2015$ : 10-11). These conceptualisations are shared and mediated also at the congregational level in a similar tone as was found in the strategic documents:

Yes it [individualisation] is a reality, but it does not exclude the longing for communality. ... Of course this individuality has to be seen as a challenge. We have to make our cause needed. ... Yes, both [new and traditional forms of spirituality] are important. And it has to be like that. You know, it is like cross-country skiing; some of us like the classic style and some of us like skate-skiing. (Interview 5)

According to my fieldwork this acknowledgement of individualisation, and need for various forms to express one's spirituality, is generally shared. This polyphony - or polarisation - of Lutheranism is the framework through which the ELCF's internal and external positions are understood. This 'church as polyphonic community' definition relates also to public discussion and media. As Mäkinen explains in his speech, the 'media is the public sphere where this shared polyphonic discussion exists' and later he continues 'there is room for as well as an expectation of the Church's presence in public discus-

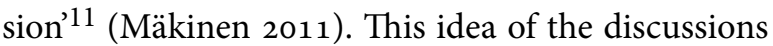

11 A rather good example of this kind of ambition and its tendencies was the open panel discussion organised in Helsinki on 13 October 2014 and reported inside and outside of the ELCF's realm, and the polyphonic nature of these discussions relates strongly to the reported and debated changes in religiosity (see Palmu et al. 2012, Heelas and Woodhead 2007, Davie 2002). Mäkinen notes that the church has not the same position today as it has had before and continues by saying: 'The church does not dominate in the public sphere (public discussions). It was the case 150 years ago. It is not the case today'. Even though the ELCF has to some degree dominated the cultural, societal and religious landscape of Finland, at the same time it has had a strong tendency to incorporate various revival movements that have arisen from its fold $^{12}$ (Aho 1964: 13).

According to some theories, the growing diversity within religion will lead to conflict, particularly between those who are deeply religious and those who have a weak religious commitment. In the Evangelical Lutheran Church of Finland, the development manifests itself, for example, as a division and juxtaposition of viewpoints in terms of values. (CoE 2015: 10)

However, the emerged controversies and debates which have arisen out of differing interpretations of faith have not been quite as visible as they are in contemporary discussions in the media. ${ }^{13}$

These processes of change in religiosity are presented as reasons for this unwanted, and somewhat unexpected change. Contemporary Finnish society is understood, in discussions inside the ELCF, to be a person-oriented society. The change in religiosity is seen amongst the ELCF's representatives as inevitable. Even though the ELCF is still dominant in the Finnish

by the National Church Council Communication Centre on their website. Archbishop Kari Mäkinen, and the Prime Minister of Finland, Alexander Stubb, talked about the meaning of the Church in Finnish society under the title 'Whose voice can be heard in the Church and in society?' where the discussion revolved around the topic of the ELCF's role in society and the ELCF as an community with multiple voices (A\&PM/News).

12 However the ELCF has mostly incorporated or allowed to exist in its fold those movements and revivals that have their roots in pieticism, yet revivals and movements coming from other Christian traditions have long been rejected.

13 On change of policies towards religion and 'state church' in the media see Taira 2015: 185-96. 
religious environment, it is considered in the ELCF that it has to respond ever more strongly to different challenges and critiques arising from multifaceted societal and religious environments. Uniformity has transformed into multiplicity inside as well as outside the ELCF's sphere of influence and this provokes a stronger justification for its significance and reason for being amongst the ELCF's representatives. In contemporary post-Christian societies believers those who affiliate themselves with Christianity - see their religion as being one amongst many. For them this increasingly problematic diversification often leads to an explicit justification of their own beliefs (Casanova 2012: 30). A slight shift in assertions as well as in argumentation is detectable; the Church becomes more and more aware of the possible threats to its position (e.g., $\mathrm{CoE}$ 2015). This justification is also visible inside the ELCF, where variable interpretations of Evangelical Lutheranism engage in debate and collide with each other. Criticisms of the ELCF are not merely external, but also internal:

Here comes the Church critique, which you can send to the Chapter ... the Church of Finland is the most civil-servant type of church in the world. Because of that ... and the fact that we have had money, we have not had to mind about people, or mind about how to motivate them. (Interview 2)

Simultaneously, the discussions about the problems and solutions at the grassroots level - that is to say the congregational level - can be described as a multifaceted problem. Firstly the traditional core operations tend to attract elderly people instead of the more challenging age groups. Secondly the traditional Evangelical Lutheran upbringing has become more diffuse or, to be more exact, there is no longer a dynamic religious culture among Evangelical Lutheran families. Thirdly, traditional forms of Evangelical Lutheranism do not offer space for individualised, or experience- and emotion-emphasising forms of expressing personal spirituality (Interview 2, Interview 3, Interview 4, Interview 5).

Local phenomena, such as the development of a worship practice and new approaches that speak to modern people, serve to enhance commitment to the church. ... The revival movements, which operate primarily on the basis of volunteer work, offer a model of commitment based on an experience of engagement. However, public discussion concerning these movements has brought internal conflict and tensions within the church to the surface.

(CoE 2015: 10-11)

Religiosity that emphasises charisma is a tempting option, as it seems to 'solve' the problems the ELCF is facing by offering more emotional and personalised ways to express one's religious affiliation, even though the ELCF perceives the possibility of controversy.

\section{Charismatic Evangelical Lutheranism: administrative legitimation and delineation}

The 'work of the Holy Spirit' in parishes has provoked discussion and debates throughout the ELCF's history. For example when Pentecostalism 'arrived' in Finland, the ELCF rejected the movement as 'zealous', and expressed their concern about the strong charismatic tendencies of the movement (Mantsinen 2014: 19, 23; Ruohomäki 2014: 447-50). However, by the year 2007 the atmosphere amongst some of the ELCF bodies and representatives had changed, and the bishops wrote the commendation in order to promote a 'healthy' charismatic Christianity (BC 2007). This Whitsunday 2007 commendation is often referred to as an important watershed amongst people who operate in or with the associations promoting charismatic religiosity in the ELCF. The discussions between ELCF, the Finnish Pentecostal Movement and the Evangelical Free Church of Finland had started as early as 1992, when the first tripartite ecumenical meeting was arranged. During the second meeting, held on 26-27 October 2001, a consideration was written stating that even though there are some differences between the denominations they all share a common ground in Christ's atonement. Furthermore the representatives of the denominations stated that they should be 'open to all positive opportunities that arise from charisma' (CCC 2001).

The Our Church strategy (OCSC) names charismatic Christianity as the fourth branch of Christendom alongside the Catholic, Orthodox and Protestant churches. It also states that the majority of charismatic Christians and charismatic Christian movements operate (and emerge from) inside the more traditional denominations (mainly Protestant 
and Catholic churches). It is also suggested that Pentecostal and charismatic movements seek more opportunities to collaborate and communicate with other denominations (OCSC 2007: 9). Later in the strategy it is stated that the 'majority of the Church's operations are channelled through various revival movements and Christian associations'. Furthermore, it is argued in the strategy that there is a multitude of assets to be made available as a consequence of more extensive collaborative and developmental operations with those movements and associations (OCSC 2007: 22). This quite clearly constructs a space for collaboration and encourages parishes to seek possible forms of collaboration beyond the traditional forms. Furthermore, it is rather clear that the attitudinal change in the ELCF and its relation to charismatic Christianity has reached the administrative level, as they are encouraging the parishes to cooperate with various denominations including Pentecostal and charismatic movements and associations.

One of the examples of this collaboration is the CBF one-day seminar entitled 'Charismatic spirituality has its place at the core of Evangelical Lutheran theology' ('Karismaattisuudella on paikka luterilaisuuden ytimessä) held on 24 April 2008 $(\mathrm{CBF}) .{ }^{14}$ During the day the floor was open for discussion about the role of charismatic spirituality inside the church and the day ended with a charismatic Mass (CBF/seminar2). However, charismatic Christianity also provokes a notable amount of controversy and discussion inside the ELCF. The Bishops' Commendation on Whitsunday 2007 was an effort to set the parameters for an emerging charismatic Evangelical Lutheranism. In the Commendation the bishops conceptualise charismas as 'the gifts of Spirit' that are the prevailing reality here and now, and describe the ELCF as the charismatic community as a whole: 'thus a Church that preaches the Word (evangelises) and distributes the sacraments is indeed a charismatic community' (BC 2007). The concept of charisma is extended to distributing the

14 Amongst the speakers were several ELCF's representatives: for example Archbishop (emeritus) John Vikström, Bishop (emeritus) Jorma Laulaja, Bishop Gustav Björkstrand, and the vicar of Mustasaari parish, Jari Friman. The first seminar was named 'Charismatic Spirituality: a problem or a possibility for the Church?' The seminars focus mainly on the role of the Church in changing religious environment and charisma (CBF/seminar1, $\mathrm{CBF} /$ seminars). sacraments and evangelisation. This is a theological decision, where the one aspect of the Trinity is to be seen as the construction and supporting force of the community as the 'body of Christ', the Church (ibid.). The Holy Spirit and His work are described in the Commendation by referring to the Large Catechism. The definition denotes the 'work of the Spirit' as a permeable power that unites every Christian in the world as well as supporting them in their faith (LC/BOC IV 42). They continue by acknowledging the more traditional definition of charismatic spirituality: 'With the term charismatic spirituality one denotes also experience-based Christianity that may incorporate healing, affections, prophecies or speaking-in-tongues (glossolalia). This is a form of spirituality that is a part of everyday life in our parishes' (BC 2007).

The last sentence of this definition is the most interesting one. By referring to charismatic spirituality as 'a form of spirituality' that is 'part of everyday life' inside the ELCF, they give an administrative legitimation and support to the usage of 'the gifts'. Furthermore, when combining this acknowledgement with previous descriptions, where the ELCF is in some degree defined as charismatic in general and throughout its history, they reclaim charismatic spirituality as a trait of Evangelical Lutheranism. However, almost simultaneously the commendation changes its tone, and the bishops express their concern:

However, this experience-based affective spirituality may be influenced by or attached to some personal endeavours. Charismatic spirituality that divides congregations, causes confusion or disparages mundane charismas does not build the Church. In proper use the charismas given to the congregation enforce the uniformity of the community and deepen the faith rooted in Jesus Christ. (BC 2007)

By means of this disclaimer, they delineate the 'wild usage of charismas' and the misdirected focus on more flamboyant charismas (glossolalia, prophesying etc.) as something to be avoided. An intriguing section in this quote is the word pairing in the expression 'mundane charismas'. It can be understood in the light of the previous sections of the Commendation. Charisma is conceptualised firstly as 'evangelisation' and 'distributing sacraments'. The mundane charis- 


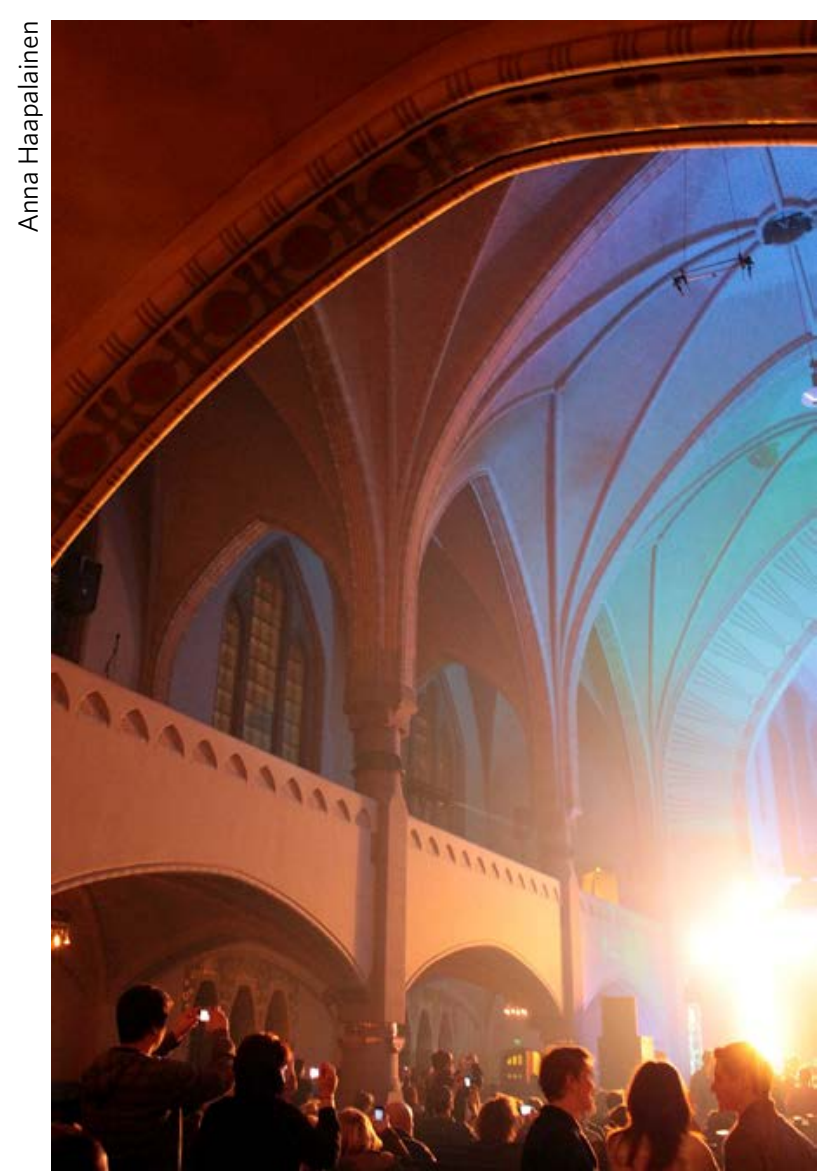

The first interdenominational Dance+Pray Mass was organized at St Michael's Church in 2012.

mas are the binding force of the congregation. The bishops continue by indicating the relation between the doctrine and religious experiences:

The faith represented in the Church and the (religious) experiences of the individuals are both dependant upon and supported by each other. Without such experiences faith withers and tapers off. Without 'sound doctrine' (2 Timothy 4:3) experience disengages itself from the shared beliefs of the Church and is in danger of drifting towards unsound individuality. Everything within the Church is to be scrutinised and evaluated in light of the Holy Word of God. (BC 2007)

The religious experiences provided by the right usage of the gifts keep the ELCF alive. Individuality is part of Evangelical Lutheranism, but it cannot be 'unsound' within the ELCF. They make a clear distinction concerning the process of charismatisation (Weber 1989: 198) and accent the guiding role of the theological premises in the process of evaluation. The bishops argue that the ELCF has the role of managing the charismas, and in this way they aim to rein in charismatic spirituality. However, the Commendation acquired great importance for the association promoting the 'work of the Holy Spirit' in Evangelical Lutheranism as well as ELCF's employees and laypeople who incorporate charisma into Evangelical Lutheranism.

\section{Charisma in action: emphasising individualised spirituality in the congregation}

One of the chaplains in St Michael's parish was head of 'operations renewal' in the year 2012. He has a close connection to SROC and the CBF (Interview 2). During our interview he told me that the Bishops' Commendation was eagerly anticipated and of the utmost importance because they were finally getting the 'administrative backup' for the work they had been doing for years. Promoting the work of the Spirit and encouraging charismatic Spirituality amongst Evangelical Lutheran parishes is important, and vital from his point of view. Firstly because, in these 'ultra-modern' times, of the emphasis on individuality before everything else, and secondly, personalised spirituality, religious experiences and emotionality are becoming more and more important as a consequence of this individualisation. Charismatic Christianity provides, according to him, these craved-for experiences and affects that are often seen to be lacking in traditional Evangelical Lutheranism, which is sometimes seen as boring or relying too strongly on teaching. In his opinion, an individual relationship to God, the 'touch of the Spirit', is vital in order to have a living faith, and yet he was very clear that these gifts are not to be used in isolation, but as a part of a community, in order to build the congregation. (Interview 2)

In several discussions in the field I often heard statements, in which the speaker juxtaposed the Pentecostal or free churches and the Evangelical Lutheran Church. They described a situation where a visitor to a Pentecostal or free church service may notice that there are people, young adults, families and new generations in the congregation, whereas in Evangelical Lutheran Sunday Mass one meets only elderly people. Often they continued by saying that these charismatic communities are doing something right. Rather often they also told me that people do not 
affiliate strongly with one parish, or even denomination, or would describe how teenagers participating in a confirmation class no longer know even the basic teachings. Individualisation and secularisation were the two key concepts that they had modest or extensive experience of (Interview 2, Interview 4, FN2012, FN2013).

All of these challenges were mentioned also in the strategies (OCSC 2007, CoE 2015). On various occasions an explanation was provided. According to these, the ELCF is in trouble, as being Evangelical Lutheran is no longer an integral part of cultural identity in Finland. During my fieldwork several ELCF representatives argued that an Evangelical Lutheran upbringing is not a cultural norm (which is also stated in the strategies), when the culture of the Pentecostal or free churches is different (Interview 2, Interview 4). They stated that in those denominations and congregations the personal testimonials are important and members participate in operations and events on a regular basis. It was often claimed by the people from St Michael's that these aspects were rare amongst the members of ELCF (Interview 4, FN2012). St Michael's parish has directed a significant portion of its resources ${ }^{15}$ into various operations and collaborative projects that support charismatic Evangelical Lutheranism (Interview 7, Interview 6, Interview 5, Interview 2).

The employees of the parish have participated in several educational events as well as seminars provided by SROC, and they have organised in collaboration with SROC these education events for the laypeople in St Michael's parish. The education packages are named 'The Source of Hope' ('Toivon lähde'), which focuses on prayer and pastoral care, and 'Emerge Holy Spirit' ('Tule Pyhä Henki'), which focuses on pneumatology and usage of the gifts of the Spirit in the construction of community-based faith

15 For example the politics of personnel recruitment have emphasised collaborative initiatives: in the year 2007 the parish hired a new deacon. This deacon was born and raised in a Pentecostal family and his election was considered to be problematic in certain circles inside the parish. A sufficient number of employees, however, supported his election (Interview 6). After this deacon had arrived in the parish collaboration between St Michael's and a few Pentecostal movements got closer, alongside an existing collaboration with the Spiritual Renewal association (FN2012).
(SROC/Prices, SoH, EHS). Emerge Holy Spirit training is a one-day course divided into two different sessions. This course is meant for employees of the parish as well as laypeople; however, the substance is somewhat elementary in its theological aspects (EHS). ${ }^{16}$ A secondary aim of the 'Emerge Holy Spirit' training's mission is to broaden the perspective concerning pneumatology, charismas and the work of the Holy Spirit (EHC). ${ }^{17}$ In addition to seminars and training packages SROC has launched a training programme called 'Spirit' ('Henki') and St Michael's representatives have taken part in this training programme (SPIRIT2). It is a programme designed for parish employees, and it aims to strengthen community building at the congregational level (SPIRIT). ${ }^{18}$ The Spirit programme is more focused on developing a networking and discussion forum, where parish employees have an opportunity to share experiences and discover new ways of promoting communality. However, both of these programmes aim to promote charismatic spirituality, religious experience, and the construction of communality (SPIRIT, LC).

It can be seen that SROC provides a multitude of different operations that seek to provide educational and training programmes and promote the work of

16 This educational programme incorporates several topics, described on the homepage as follows: the three decades of the Spirit; the Holy Spirit as a person; human beings as the temples of the Spirit; the Holy Spirit in the Bible; the Holy Spirit in the Evangelical Lutheran confession; what the Holy Spirit does; to be born from Holy water and Spirit. The programme is described as a basic teaching concerning the theology of the Holy Spirit, and the goal is to provide basic knowledge and elementary resources for the participants in order to familiarise them with the 'works of the Spirit' as well as illuminating the Biblical background of pneumatology (EHS).

17 During the course of the programme the Holy Spirit is presented as the Spirit of prayer, peace and praise. The course of study also includes a scrutiny of how to receive charismas and how to deal with exorcism and the 'spirit world'. Topics such as pastoral care and 'ordering the Spirit' are also scrutinised. The day ends with discussions about the Holy Spirit constructing congregations and what is the congregation's place in the body of Christ (EHC).

18 They also collaborate with pastors from the Lutheran Church of Denmark and pastors from the Church of England, who are affiliated with an organisation called 3 DM Europe, in organising the 'Learning Community' training programme (LC, $3 \mathrm{DM})$. 


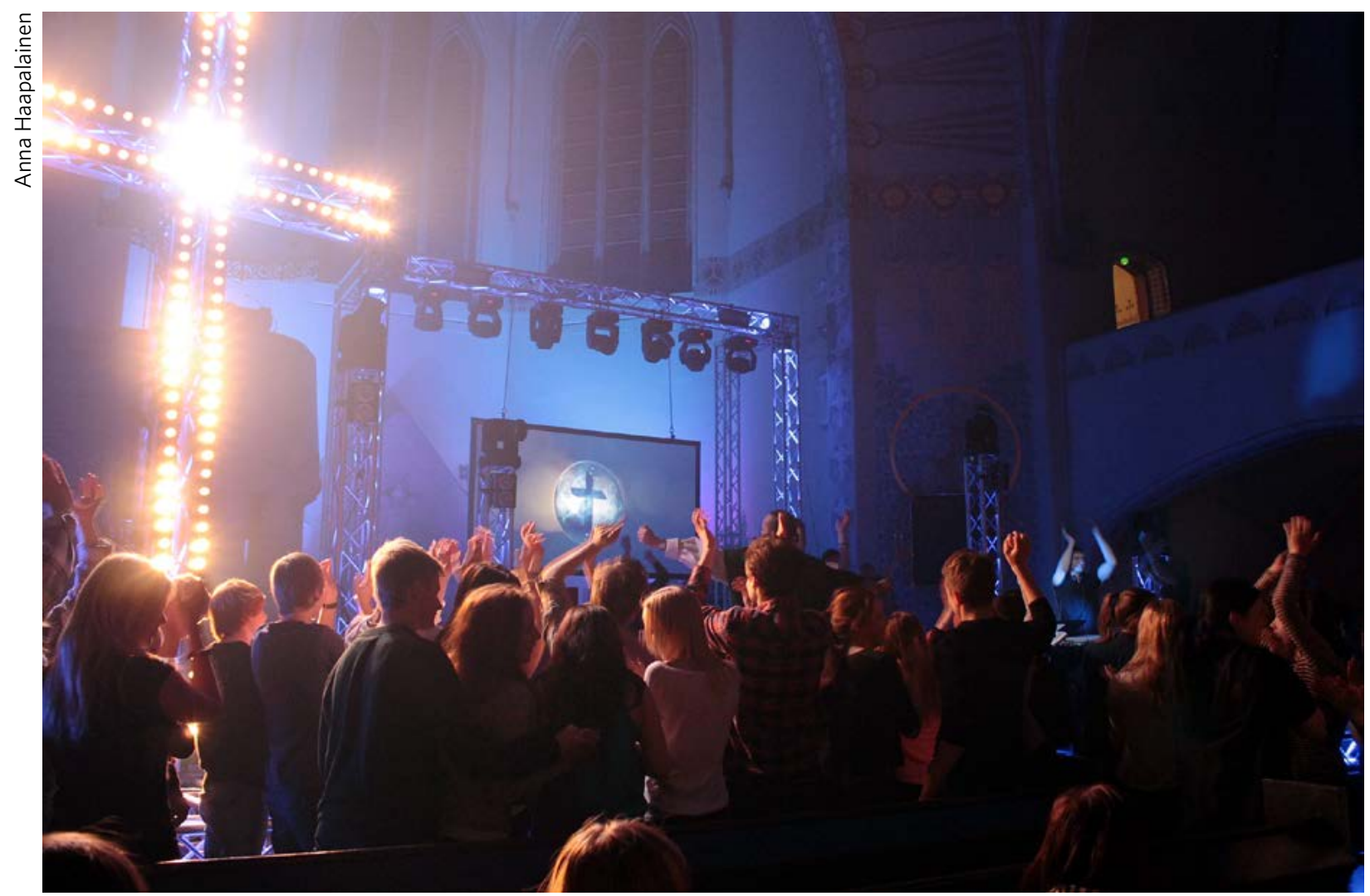

Young people dancing and praising during the Dance+Pray Mass in front of the St Michael's Church altar in 2013.

the Spirit amongst the ELCF and its employees, as well amongst the laypeople. Its educational profile is in line with the ELCF's understanding of the rise of individuality. The Bishops' Commendation is referred to in several places on th SROC homepage and they describe it as a watershed in relations between the ELCF and their association. They offer communality as an answer to the challenge of individualisation and emphasise the meaning of individual religious experiences in the development of communality in the parishes. This conceptualisation of contemporary 'problems', and the response to the challenge of a changing religious environment is in harmony with the conceptualisations of these problems provided by the ELCF (Palmu et al. 2012, OCSC 2007, CoE 2015). One might even say that they almost go hand in hand.

St Michael's parish has been the scene of a pilot community project which was launched in 2012. This project focused on fortifying parish membership by building stronger communality, discovering different forms of reaching out and strengthening voluntary work in the parish (PC). Under the umbrella of this project a number of sub-projects were conducted. The first of two main projects was to build a 'living and enthusiastic' community attached to the St
Michael's Mass. The goal was to reach out, find, and engage 200 regular parish members who would eventually form a St Michael's Mass community. Among this community they strove to find volunteers whose vision, activity and service would contribute to the arrangement of the Mass. One of the central goals was to find those volunteers who could bring in new people to join the congregation of the Mass, who would eventually see themselves as active parish members. To this end they planned developmental activities - one could call them sub-projects - such as the Alpha Group, Bible School, Emmaus School (Disciple School) and Christian Cells (PC). ${ }^{19}$ On the SROC and the Church Builders' Forum sites the aims

19 The other main project entailed the development of a social work (diakonia) community in Paakarla, which is one of the suburbs located within the parish. This social work community had a connection to the Mass community and the aim was that both of the communities would support each other. The Paakarla community (PC) is described as follows: 'The Paakarla community actively reaches out and its focus is to empower inhabitants of Paakarla to serve each other by sharing the Word and by participating in social work which benefits the whole community? 
and objects of this collaboration were elaborated as follows: 'During this project an interactive discussion will be conducted in CBF seminars, utilising the operation models developed in the seminars and importing their findings into everyday work in the parish of the seminars' (PC).

During this pilot project a one-day seminar named 'Emerge Holy Spirit' was organised in St Michael's in the spring of 2012 (FN2012). In addition to this study for parish employees and laypeople, several other related operations were conducted, in which the topics revolved around charismatic Christianity, individuality, communality, community building and charismatic spirituality as aspects of the construction of the parish. The Tuesday Bible School also organised some longer weekend events, such as the 'St Michael's Winter Days' and 'Encounter Place ('Kohtaamispaikka') services; a well-known healer was even invited to attend an event. At this event, as well as several others, prophecies, speaking in tongues, and other charismas were in use. At many congregational gatherings songs associated with the Pentecostal movement ${ }^{20}$ were sung, and people raised their hands in praise. One chaplain of the parish said that they advertise events in other Evangelical Lutheran parishes but also in other, mainly Pentecostal or free church, congregations. An active layman stated during the coffee break of one event that rather a lot of Pentecostal and free church members participate in St Michael's worship events and weekends (FN2012). It was often mentioned that inspiration is also sought from the Christian field globally, where for example Hillsong, Vineyard and the work done at the Santa Clara Kyrkan (Stockholm, Sweden) are models for the St Michael's parish. (Interview 2, Interview 1; FN2012, FN2013)

In the OCSC strategy the definition of missionary work emphasises how a Christian mission always begins in the homeland. The idea of the ELCF as a polyphonic community also indicates that the individuals have different and varying life situations and spiritual needs. Evangelisation is a process of giving room for this variation, and the creation of opportunities to find and fulfil Christianity in one's life: 'We support the birth of small operational groups and

20 For example, 'Golgatan veressä voima on' ('With the Blood of Golgotha Comes Power') written and composed by Pentecostal preacher and songwriter Paavo Virtanen. communities and support the various opportunities whereby the members (of the Church) may be able to develop activities and create new forms of operation' (OCSC 2007: 39). One aim is to encourage voluntary work in the parishes (ibid. 42). Voluntary work is often seen as a perfect solution at the parishional level, because it eases economic stress and at the same time offers opportunities for individuals from the lay community to participate, develop and contribute.

In St Michael's parish voluntary work is done in various ways, ranging from from the traditional shifts in the soup kitchen to voluntary work related to charismatic spirituality. The pastor noted that previously, when the ELCF had money, it had, because of that, not 'minded about people'. Minding about the motivation, in his opinion, is related to opportunities to express and live out one's faith in the construction of the community (Interview 2). The Emerge Holy Spirit education day, the community project in Paakarla-Pansio, Alpha Groups, services concentrating on charismatic worship, small group activities and Christian cells all provide opportunities relating to this charismatic form of volunteering; these are the ways in which people find personalised ways of expressing religiosity and spirituality in order to 'build the congregational communality'.

The close collaboration between SROC and St Michael's Parish has generated an enforced undercurrent of charismatic spirituality inside the parish. Charismatic spirituality, which has been always a part of the ELCF and its revival movements, has acquired greater visibility and justified its position inside the parish. When scrutinising the statements encountered during fieldwork, it can be quite confidently argued that the discussions and operations which are happening in St Michael's are in line with the goals, mission and aims of both the ELCF and SROC. It can be described as a cycle of influence, where an emerging interest in charismatic spirituality prompts, in the long run, the ELCF to respond (resulting in the Bishops' Commendation). Furthermore this response encourages the associations to promote charismatic Christianity by offering them an administrative 'blessing', and finally leads to actualisation at the operational level in the form of a dynamic collaboration between the ELCF and SROC, as well as an ever closer collaboration between charismatic movements, associations promoting charismatic spirituality and Evangelical Lutheran parishes at the grassroots level. 


\section{Conclusion}

Christianity has been considered to be flexible and diversified and its stronghold has been in Western societies. However, this image has changed since global Christian trends have begun to emerge outside the traditional sphere. Mainline churches influence Christianity, but alongside these a multitude of Christian, especially charismatic, movements have a great deal of influence in the Christian field globally (Robbins 2010: 156-8; Woodhead 2009: 327; Anderson 2004: 1-15; Walker 2000; Bebbington 2000; Ahonen 2003: 129-35). Charismatic Christianity incorporates a multitude of variations, and it can be understood to be an open-class concept which modifies according to given temporal and spatial contexts. However, the emphasis on personalised faith, experience-based spirituality, and charisma are common denominators among the charismatic movements (Anderson 2004: 1-15, 23-5; Ahonen 2003: 129-35; Walker 2000; Bebbington 2000). This global Christian field is a source of inspiration for various individuals and bodies within the ELCF. At the individual level this inspiration seeking has been quite normal even for the pastors, but it is also systematically conducted more and more at the communal level. People within the ELCF are finding inspiration from denominations that are considered close to Evangelical Lutheranism in this situation, in which the ELCF recognises that it is in 'crisis'. However, this process of recognition also creates the reality. It defines the problems to be addressed and simultaneously some ELCF representatives use these definitions as the causal explanation for the key question: 'Why people are fleeing from the fold?'

The commendations and strategies produced by ELCF are texts that have a specific intention; they are produced and distributed in order to bolster uniformity in a polarised ELCF. They are written to address a core vision that can be shared by all members of the ELCF. At the same time they produce a reality by describing the environment and situation in which the ELCF stands. Furthermore, they actualise at the congregational level, where they are used to steer as well as justify operations.

The changes, the challenges, and even the emergence of individuality and secularisation are considered to be the work of God. 'The world does His bidding' type of language is often used, yet simultaneously the position of human beings is seen to be to trust and obey the Lord. However this trust and obedience is not considered to be passive, but needs must entail active attempts at revival and renewal (e.g., CoE 2015: 14-15; Interview 2; Interview 3; FN2013; FN2012). Furthermore, when depending so strongly on the Word, and faith, it allows the conviction, and alongside that the interpretation of faith, to play a rather significant role. Each word, phrase, sentence, chapter or book can be read through one's own understanding of what Evangelical Lutheranism is, what it is to believe, what is faith, what are values, and so forth. The meaning of certain concepts is not fixed, but fluid and flexible. What is written in strategies, and spoken in seminars and schooling events carries a meaning. However, the way it is received is always at best ambiguous. In St Michael's one of the chaplains understands the concept 'personalised spirituality' in the context of charismatic spirituality and the importance of 'the gifts of Spirit' to the parish and its members, whereas one of the youth workers sees it more or less through the lens of every-day religiosity (Interview 2, Interview 3). The both of these interpretations are in line with the ELCF's strategies and the Bishops' Commendation.

The conceptualisations provided by the ELCF seep quietly into the everyday discussions taking place in St Michael's parish. Based on these strategies, the parish employees plan the operations within their remit. They interpret the language and concepts used and adjust them to their own interpretations of faith, religion, society, individualisation and spirituality. They collaborate with various associations according to their understanding of what ought to be done in order to stop the unwanted change. The emergence of a charismatic Evangelical Lutheranism as an everyday congregational phenomenon is parallel to the case of Healing Rooms presented by Tuija Hovi:

As the case of Healing Rooms indicates, religious movements, traditions or ideas do not travel, develop and become global by themselves; not even Pentecostal ones. They need culturally sensitive agents and actors, as well as a suitable timing and right social context setting in order to be introduced into new contexts.

(Hovi 2015: 90)

On looking this situation at various levels - administrative, grassroots, and cooperative - it can be said that there is room for charismatic religiosity in the ELCF, and there is obviously a need for it. Because 
of the several decades of work done by SROC, the publication of the Bishops' Commendation and the Church's awakening to the 'crisis of the folk church', more doors have opened to collaboration and inspiration seeking. It can't be stated that the Evangelical Lutheran Church has become charismatic as a whole, but it surely is reaching towards charismatic religiosity and spirituality.

\begin{abstract}
MA Anna Haapalainen is currently finalising her $\mathrm{PhD}$ thesis on the Evangelical Lutheran Church of Finland and its relation to the changing religious environment in Finland. Her interest areas are Christianity, secularisation, post-secularisation, power, transformation and agency. She works at the department of Comparative Religion at the University of Turku.
\end{abstract}



\section{References}

Electronic materials

3DM. '3D Movements: discipleship \& mission homepage, webpage maintained by $3 \mathrm{DM},<\mathrm{http}: / /$ weare $3 \mathrm{dm}$ store.3dcartstores.com $>$ (accessed 31.5.2015)

A\&PM/News. 'Arkkipiispa ja pääministeri keskustelivat kristinuskosta ja kirkon merkityksestä yhteiskunnassa' [Archbishop and Prime Minister discussed about Christianity and the meaning of the Church in society], National Church Council, Communication Centre, 13.10.2014, <http://evl.fi/EVLUutiset.nsf/o/29 168E7245BEFB46C2257D700062BA6B?opendocume nt\&lang $=\mathrm{FI}<($ accessed 4.12.2014)

BC 2007. 'Piispojen tervehdys helluntaina' [Bishops' Commendation], 27.5.2007, document provided by Church's Builders' Forum: Bishops Jukka Paarma, Eero Huovinen, Voitto Huotari, Wille Riekkinen, Juha Pihkala, Samuel Salmi, Mikko Heikka, Simo Peura, Kari Mäkinen, and Gustav Björkstrand, <http://www. kirkonrakentajienfoorumi.fi/kirkonrakentajien_foorumi/foorumin_tarkoitus_ja_jasenet/piispojen_tervehdys_helluntaina_2752007/> (accessed 16.10.2014

CBF. Church Builders' Forum, 'Karismaattisuudella on paikka luterilaisuuden ytimessä [Charismatic spirituality has its place in the core of Evangelical Lutheran theology], website maintained by the Spiritual Renewal in Our Church, <http://www.kirkonrakentajienfoorumi.fi/kirkonrakentajien_foorumi/karismaattisuus_luterilaisen_teologian_ytimessa/> (accessed 16.10.2014)

$\mathrm{CBF} /$ seminar1. Church Builders' Forum, 'Karismaattisuus. Kirkon ongelma vai mahdollisuus' [Charismatic spirituality: Church's problem or possibility], 11.9.2007, webpage maintained by the Spiritual Renewal in Our Church, <http://www.kirkonra- kentajienfoorumi.fi/kirkonrakentajien_foorumi/ seminaarit/aiemmat_seminaarit_sanoin_ja_kuvin/ syksyn_2007_seminaari_karismaattisuudesta_kopio/> (accessed 31.5.2015)

CBF/seminar2. Church Builders' Forum, 'Karismaattinen kirkko. Mitä se on?' [Charismatic church: what is it?], 21.4.2008, webpage maintained by the Spiritual Renewal in Our Church, <http://www.hengenuudistus.fi/kirkonrakentajien_foorumi/seminaarit/ aiemmat_seminaarit_sanoin_ja_kuvin/karismaattinen_kirkko_-_mita_se_on_lahetyskirkko_2142008/> (accessed 31.5.2015)

$\mathrm{CBF} /$ seminars. Church Builders' Forum, 'Aiemmat seminaarit sanoin ja kuvin' [Previous seminars in word and pictures], webpage maintained by the Spiritual Renewal in Our Church, <http://www.kirkonrakentajienfoorumi.fi/kirkonrakentajien_foorumi/ seminaarit/aiemmat_seminaarit_sanoin_ja_kuvin/ (accessed 31.5.2015)

CCC 2001. Ilkka Kantola, Valtter Luoto, and Olavi Rintala, 'Karismaattisuus on haaste kirkolle' [Charismatic Christianity is a challenge to the Church], webpage maintained by the Evangelical Lutheran Church of Finland and Church Communications Centre, <http://www.evl.fi/kkh/kt/uutiset/mar2001/karisma. htm $>$ (accessed 14.9.2015)

CM. 'Seurakuntien jäsenistö 2014' [Congregation memberships 2014], website maintained by Evangelical Lutheran Church of Finland and Church Communications Centre, <http://sakasti.evl.fi/sakasti.nsf/ sp?open\&cid=Content 3 D45B8 $>($ accessed 27.4.2015)

CMS 2014. 'Kirkkona monikulttuurisessa yhteiskunnassa' [Church in Multicultural Society], Suomen evankelisluterilaisen kirkon tulevaisuusselonteko, Suomen ev.-lut. kirkon julkaisuja, Kirkko ja toiminta, 16 (Helsinki, Kirkkohallitus), <http://sakasti.evl.fi/ sakasti.nsf/o/E29Bo943AD270895C2257D72002DEB 96/\$FILE/Kirkkona_monikulttuurisessa_yhteiskunnassa.pdf $>$ (accessed 14.9.2015)

CoE 2015. 'A Church of Encounter', website maintained by the Evangelical Lutheran Church of Finland, <http://sakasti.evl.fi/sakasti.nsf/ sp?open\&cid=Content $2656 \mathrm{~A} 1>($ accessed 25.9 .2015$)$

CS. 'Kirkko ja valtio' [Church and State], website maintained by the Evangelical Lutheran Church of Finland, $<$ http://evl.fi/EVLen.nsf/Documents/894E3D73E89D 172CC2257C 310041 DoBF?openDocument\&yp=y\&la $\mathrm{ng}=\mathrm{EN}>($ accessed 27.4.2015)

CSC. 'Seurakuntien väestömuutokset - seurakuntien jäsenistö’ [Congregational societal changes], website maintained by the Evangelical Lutheran Church of Finland, <http://sakasti.evl.fi/sakasti.nsf/o/88F3966 $\mathrm{F}_{93} \mathrm{C}_{98} \mathrm{AB}_{2} \mathrm{C}_{22} 27995003 \mathrm{C}_{9} \mathrm{C}_{2} \mathrm{C} / \$ \mathrm{FILE} /$ seurakuntien_vaestonmuutokset_2013_final.pdf $>$ (accessed 18.10.2014)

EHS. 'Opetuspaketti “Tule Pyhä Henki”' [Education package 'Emerge Holy Spirit'], webpage maintained by the Spiritual Renewal in Our Church, <http://www. hengenuudistus.fi/hengen_uudistus_kirkossamme/ 
opetuspaketit_seurakuntiin/tule_pyha_henki/> (accessed 16.10.2014)

ELCF homepage. The Evangelical Lutheran Church of Finland homepage, <http://evl.fi/EVLen.nsf> (accessed 27.4.2015)

LC. 'Learning Community -valmennus' [Learning Community training], webpage maintained by the Spiritual Renewal in Our Church, <http://www.hengenuudistus.fi/yhteisot/learning_community-valmennus/> (accessed 31.5.2015)

LC/BOC. 'The Large Catechism: The Book of Concord 1921' in Triglot Concordia: The Symbolical Books of the Evangelical Lutheran Church: German-Latin-English, Evangelical Lutheran Synod of Missouri, Ohio, and Other States (St Louis, Concordia Publishing House)

Mäkinen, Kari, 2011. 'Moniäänisyys edellyttää aikuisuutta, nöyryyttä ja rohkeutta' [Polyphonic discussion requires us to be adult, humble and courageous], opening words at the Evangelical Lutheran Church's Synod, 2.5.2011, <http://www.evl.fi/arkkipiispa/ Kirkolliskokousavauso2052011.htm $>$ (accessed 24.5.2015)

NBPR. Spiritual Renewal in Our Church association's registration information, webpage maintained by the National Board of Patents and Registration, <http://yhdistysrekisteri.prh.fi/pertied. htx?kieli=3\&reknro=151932 $>($ accessed 29.5.2015)

OCSC 2007. Meidän kirkko. Osallisuuden yhteisö. Suomen kirkon strategiaa vuoteen 2015 laatineen työryhmän mietintö [Our Church: shared commonwealth], Suomen evankelis-luterilaisen kirkon keskushallinto, Sarja C 2007:10 (Helsinki, Kirkkohallitus), website maintained by the Evangelical Lutheran Church of Finland, <http://sakasti.evl.fi/sakasti.nsf/o/9297F603 C875C1C8C225770Aoo2E3448/\$FILE/kirkon_strategia_2015_mietinto.pdf $>$ (accessed 29.5.2015)

OSF. Official Statistics of Finland, Population Structure (Helsinki, Statistics Finland, 2013), <http://tilastokeskus.fi/til/vaerak/2013/vaerak_2013_2014-03-21_ tie_001_en.html?ad=notify $>($ accessed 27.4.2015)

PC. 'Pilottiseurakunnat - Turun Mikaelinseurakunta' [Pilot congregations, St Michael's Parish], webpage maintained by the Spiritual Renewal in Our Church, $<$ http://kirkonrakentajienfoorumi.fi/kirkonrakentajien_foorumi/pilottiseurakunnat/mikaelinseurakunta_turku/> (accessed 16.10.2014)

SC. 'Seurakuntien väestömuutokset' [Societal change], information provided by Evangelical Lutheran Church of Finland, based on information provided by Statistic Finland, <http://sakasti.evl.fi/sakasti.nsf/o/ FFEDB75916EB394AC22576CCo03D875E/\$FILE/ seurakuntien_vaestonmuutokset_2014_20042015. pdf $>$ (accessed 27.4.2015)

SoH. 'Opetuspaketti “Toivon lähde”' [Education package 'The Source of Hope'], webpage maintained by the Spiritual Renewal in Our Church, <http://www. hengenuudistus.fi/hengen_uudistus_kirkossamme/ opetuspaketit_seurakuntiin/toivon_lahde/koulutuksen_sisalto/> (accessed 31.5.2015)
SPIRIT. 'Spirit-valmennus' [Spirit training], webpage maintained by the Spiritual Renewal in Our Church, $<$ http://www.hengenuudistus.fi/yhteisot/spirit-valmennus $/<$ (accessed 31.5.2015)

SPIRIT2. 'Spirit 2015 promo-video', <http://www.hengenuudistus.fi/?document $=14683304 \&$ hitspic $=10$ \&hit spage $=1>($ accessed 29.09.2015)

SROC/Mission. 'Tavoitteet ja toiminta' [Goals and operations], webpage maintained by Spiritual Renewal in Our Church, <http://www.hengenuudistus.fi/hengen uudistus_kirkossamme/> (accessed 29.5.2015)

SROC/Prices. 'Toivon lähde -koulutuksen hinta' [Education packages and prices for congregations], webpage maintained by Spiritual Renewal in Our Church, $<$ http://www.hengenuudistus.fi/hengen_uudistus_ kirkossamme/opetuspaketit_seurakuntiin/toivon_lahde/koulutuksen_hinta_ja_kustannukset/> (accessed 8.6.2015)

StMP. St Michael's Parish, homepage, website maintained by Turku and Kaarina Parish Union, <https://www. turunseurakunnat.fi/portal/fi/seurakunnat/mikaelinseurakunta/> (accessed 27.4.2015)

TKPU homepage. Turku and Kaarina Parish Union, homepage, <https://www.turunseurakunnat.fi/portal/ en/home/> (accessed 27.4.2015)

Fieldwork material

FN2012. Anna Haapalainen's fieldnotes, 2012, personal archives

FN2013. Anna Haapalainen's fieldnotes, 2013, personal archives

Interview 1. St Michael's Parish layman, interviewer Anna Haapalainen, 28.6.2012

Interview 2. St Michael's Parish employee, interviewer Anna Haapalainen, 30.11.2012

Interview 3. St Michael's Parish employee, interviewer Anna Haapalainen, 24.1.2013

Interview 4. St Michael's Parish employee, interviewer Anna Haapalainen, 15.3.2013

Interview 5. St Michael's Parish employee, interviewer Anna Haapalainen, 3.7.2013

Interview 6. St Michael's Parish layman, interviewer Anna Haapalainen, 9.4.2014

Interview 7. St Michael's Parish layman, interviewer Anna Haapalainen, 1.1.2015

\section{Bibliography}

Aho, Gerhard, 1964. 'Evangelical Lutheran Church of Finland: a brief survey of its history, organization and doctrinal complexion', Springfielder, 28(2), pp. 7-17

Ahonen, Risto A., 2003. 'Karismaattinen ja evankelikaalinen hengellisyys' in Spiritualiteetin käsikirja, eds S. Häyrynen, H. Kotila and O. Vatanen (Helsinki, Kirjapaja), pp. 129-50

Anderson, Allan Heaton, 2014. An Introduction to Pentecostalism: Global Charismatic Christianity, 2nd edn (Cambridge University Press)

Bebbington, D. W., 200o. 'Evankelikalismi' in Modernin Teologian Ensyklopedia, Finnish translation editor- 
ial board P. Annala, P. Järveläinen, and A. Saarelma (Helsinki, Kirjapaja)

Borg, Sami, Kimmo Ketola, Kimmo Kääriäinen, Kati Niemelä, and Pertti Suhonen, 2007. Uskonto, arvot ja instituutiot. Suomalaiset World Values -tutkimuksissa 1981-2005 (Tampere, Yhteiskuntatieteellisen tietoarkiston julkaisuja, 4)

Casanova, José, 2012. 'Are we still secular? Explorations on the secular and the post-secular' in Post-Secular Society, eds Peter Nynäs, Mika Lassander and Terhi Utriainen (New Brunswick and London, Transaction Publishers), pp. 27-46

Coleman, Simon, 2000. Globalisation of Charismatic Christianity: Spreading the Gospel of Prosperity (Cambridge University Press)

Davie, Grace, 1994. Religion in Britain since 1945: Believing without Belonging (Oxford, Blackwell)

-200o. Religion in Modern Europe: A Memory Mutates (Oxford University Press)

-2002. Europe, the Exceptional Case: Parameters of Faith in the Modern World (Darton, Longman and Todd)

Davie, Grace, Paul Heelas, and Linda Woodhead, 2003. Predicting Religion: Christian, Secular and Alternative Futures (Aldershot, Ashgate)

Day, Abby, 2009. 'Believing in belonging: an ethnography of young people's constructions of belief', Culture and Religion, 10(3), pp. 263-78

-2010. 'Propositions and performativity: relocating belief to the social', Culture and Religion, 11(1), pp. 9-30

Flanagan, Kieran, and Peter C. Jupp, 2007. Sociology of Spirituality (Aldershot, Ashgate)

Gilliat-Ray, Sophie, 2005. "Sacralizing” sacred space in public institutions: a case study of the prayer space at the Millennium Dome', Journal of Contemporary Religion, 20(3), pp. 357-72

Heelas, Paul, and Linda Woodhead, 2007. The Spiritual Revolution: Why Religion is Giving Way to Spirituality (Oxford, Blackwell Publishing)

Heininen, Simo, and Markku Heikkilä, 1997. Suomen kirkkohistoria (Helsinki, Edita)

Heino, Harri, 1997. Mihin Suomi tänään uskoo (Porvoo, WSOY)

Hovi, Tuija, 2015. 'Localising and acculturating the global: the Healing Rooms prayer service network in Finland', Approaching Religion, 5(1), pp. 79-91

Huotari, Voitto, 1981. Kirkkomme herätysliikkeet tänään (Helsinki, Kirjapaja)

Iqtidar, Humeira, and David Lehmann, 2012. 'Introduction: diversity of fundamentalism' in Fundamentalism and Charismatic Movements, vol. 1, Issues of Definition, General Theories and Historical Context, eds Humeira Iqtidar and David Lehmann (London, Routledge), pp. 1-12

Kääriäinen, Kimmo, Kati Niemelä, and Kimmo Ketola, 2003. Moderni kirkkokansa. suomalaisten uskonnollisuus uudella vuosituhannella (Tampere, Kirkon tutkimuskeskuksen julkaisuja, 82)

-2005. Religion in Finland: Decline, Change and Trans- formation of Finnish Religiosity (Tampere, The Church Research Institute Publications, 54)

Kirkon tilastollinen vuosikirja, 2006. Kirkon tilastollinen vuosikirja 2006 (Helsinki, Kirkkohallitus, 2007)

Mantsinen, Teemu T., 2014. Helluntalaiset luokkakuvassa. Uskontokulttuuri ja yksilön luokka-asemaa Turun Helluntaiseurakunnassa (Turku, Annales Universitatis Turkuensis, $\mathrm{C}_{3} 87$ )

Meintel, Deirdre, 2014. 'Religious collectivities in the era of individualization', Social Compass, 61(22), pp. 195-206

Mikkola, Teija, Kati Niemelä, and Juha Petterson (eds), 2006. Urbaani usko. Nuoret aikuiset, usko ja kirkko (Tampere, Kirkon tutkimuskeskuksen julkaisuja, 96)

Palmu, Harri, Hanna Salomäki, Kimmo Ketola, and Kati Niemelä, 2012. Haastettu kirkko (Tampere, Kirkon tutkimuskeskuksen julkaisuja, 115)

Pesonen, Heikki, and Kari Mikko Vesala, 2007. 'Rural development as a frame analytic challenge for religious communities: the case of rural parishes of the Evangelical Lutheran Church of Finland', Social Compass, 54(2), pp. 281-93

Pihkala, Juha, 200o. 'Epätervettä karismaattisuutta', Aamulehti, 31.12.2000

Puumala, Anne, 2007. 'Harhaoppinen', Savon Sanomat, 13.5.2007

Robbins, Joel, 2010. 'Anthropology of religion' in Studying Global Pentecostalism: Theories and Methods, eds Allan Anderson, Michael Bergunder, André Droogers, and Cornelis van der Laan (Berkeley, University of California Press), pp. 156-78

Ruohomäki, Jouko, 2014. Suomen helluntailiikkeen synty, leviäminen ja yhteisönmuodostus 1907-1922 (Keuruu, Aikamedia)

Salonen, Kari, Kimmo Kääriäinen, and Kati Niemelä, 200o. Kirkko uudelle vuosituhannelle, Suomen evankelis-luterilainen kirkko vuosina 1996-1999 (Tampere, Kirkon tutkimuskeskus)

Synan, Vinson, 2001. 'Streams of renewal at the end of the century' in The Century of the Holy Spirit: 100 Years of Pentecostal and Charismatic Renewal, 1901-2001, ed. Vinson Synan (Nashville, Thomas Nelson), pp. $349-80$

Taira, Teemu, 2015. Pehmeitä kumouksia (Turku, Eetos)

Walker, Andrew, 2000. 'Helluntailaisuus ja karismaattinen kristillisyys' in Modernin Teologian Ensyklopedia, Finnish translation editorial board P. Annala, P. Järveläinen, and A. Saarelma (Helsinki, Kirjapaja)

Weber, Max, 1989. Maailmanuskonnot ja moderni länsimainen rationaalisuus. Kirjoituksia uskontososiologiasta (Tampere, Vastapaino)

Woodhead, Linda, 2009. Christianity. Religions in the Modern World: Traditions and Transformations, eds Linda Woodhead, Hiroko Kawanami, and Christopher Partridge, 2nd edn (London, Routledge) 